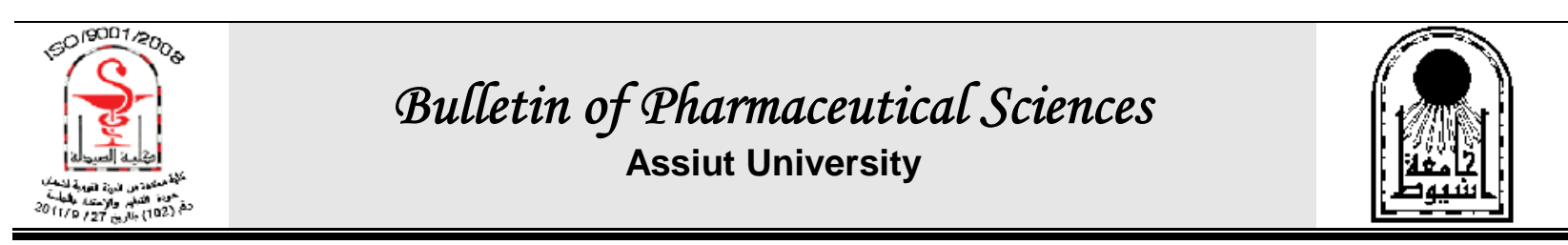

\title{
MACRO- AND MICROMORPHOLOGICAL STUDY OF LAGENARIA SICERARIA (MOLINA) STANDL.
}

Maher M. El-Domiaty, Mahmoud M. Abdel Aal, Zeinab I. A. El-Sayed* and Nora T. Wasfey

Department of Pharmacognosy, Faculty of Pharmacy, Zagazig Univeristy, Zagazig 44519, Egypt

Macro- and micromorphological study of Lagenaria siceraria (Molina) Standl., was carried out with the aim of finding out the characteristic features of the different organs of the plant in both entire and powdered forms. 


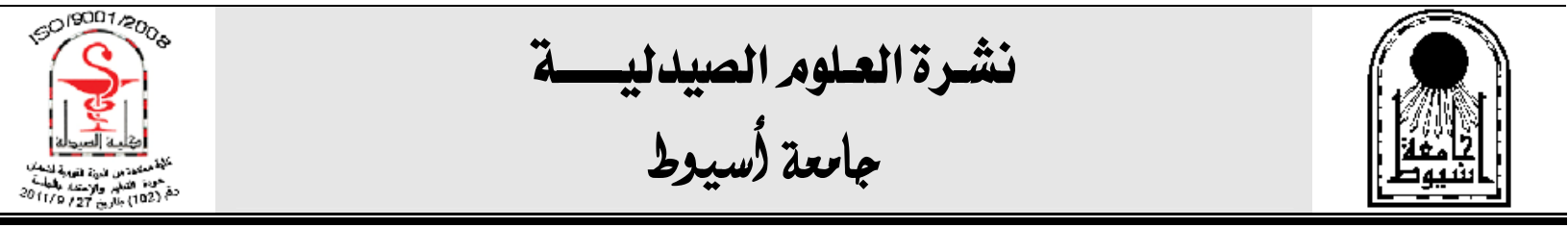

دراسة الصفات العيانية و المجهرية لنبات لاجيناريا سيسراريا (مولينا) ستاندل

ماهر محمد على الامياطى محمود محمد إبرهيم عبد العال زينب إيرهيم عبد الحميد السيد نورا توفيق آحمد وصفى عيد ائمال

$$
\text { قسم العقاقير ، كلية الصيدلة ، جامعة الزقازيق ، مصر }
$$

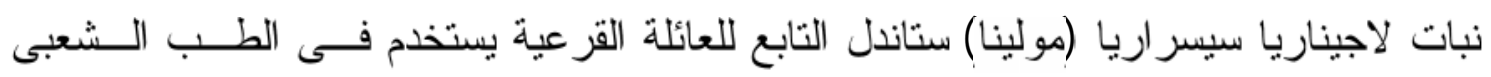

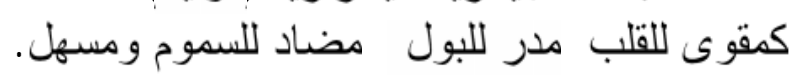

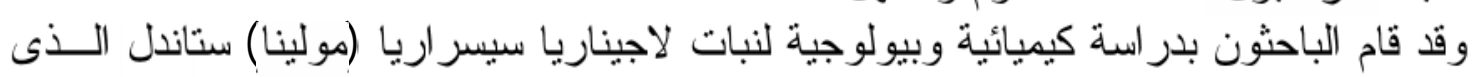

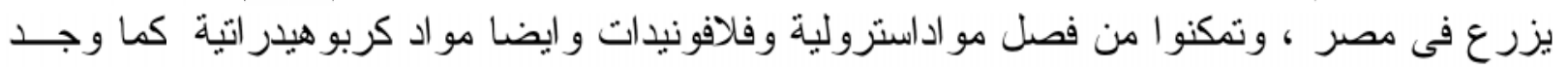

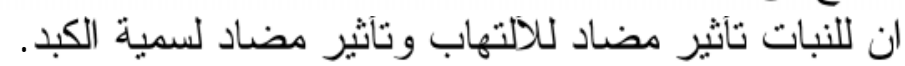

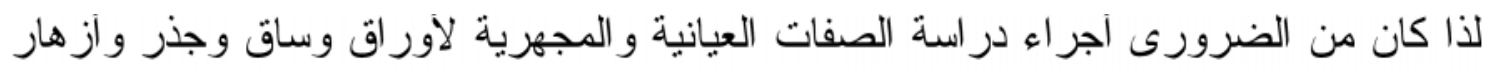
وثمار هذا النبات حتى بسهل التعرف علية فى حالتة الصحيحة او على هيئة مسحوق. 